\title{
First Record of the Isolation, Identification and Biological Activity of a New Strain of Spirillospora albida from Thai Cave Soil
}

\author{
Nareeluk Nakaew ${ }^{1}$, Wasu Pathom-aree ${ }^{2}$ and Saisamorn Lumyong ${ }^{2 *}$ \\ ${ }^{1}$ Department of Biotechnology, Graduate School, Chiang Mai University, Chiang Mai 50200, Thailand \\ ${ }^{2}$ Department of Biology, Faculty of Science, Chiang Mai University, Chiang Mai 50200, Thailand
}

(Received Nov. 4, 2008 / Accepted Feb. 26, 2009 / Published May 15, 2009)

\begin{abstract}
An actinomycete, designated as CMU-PNK470, was isolated from the soil in Phanangkoi cave in northern Thailand and subjected to phenotypic and genotypic characterization. Morphological and chemical properties indicated that this isolate belonged to the genus Spirillospora. Phylogenetic analysis based on 16S rRNA gene sequencing confirmed its placement in the genus Spirillospora and it was most closely related to Spirillospora albida (98.86\%). This is the first reported isolation of Spirillospora albida from a cave habitat. The crude extract of this strain showed antimicrobial activity against three Gram-positive bacteria, Bacillus cereus and Methicillin-resistant Staphylococcus aureus with a MIC value of $23.1 \mu \mathrm{g} / \mathrm{ml}$ and Paenibacillus larvae with a MIC value of $185 \mu \mathrm{g} / \mathrm{ml}$. It also reduced the number of viable Human Small lung cancer cells (NCI-H187) to less than $50 \%$ at a concentration of $10.18 \mu \mathrm{g} / \mathrm{ml}$.
\end{abstract}

\section{INTRODUCTION}

Rare actinomycetes (non-streptomycetes) are become an increasingly attractive source in the search for new antibiotics to fight drug resistance (Lazzarini et al., 2000). Due to isolation difficulties from natural sources and cultivation and preservation complications, they have not been extensively studied. The genus Spirillospora was first proposed by Couch in 1963 for sporangia forming actinomycetes with motile spores and was placed in the family Thermomonosporaceae on the basis of $16 \mathrm{~S}$ rRNA sequences and chemotaxonomic data (Zhang et al., 1998). It comprises only two species, Spirillospora albida and Spirillospora rubra.

Caves are generally nutrient-poor habitats with low temperatures and high humidity (Schabereiter-Gurtner et al., 2002). They are regarded as excellent sources for the discovery of novel strains of actinomycetes (Barton, 2006). Several new species have been isolated from cave soils including Catelliglobosispora koreensis from a gold mine cave in Korea (Ara et al., 2008), Agromyces salentinus and Agromyces neolithicus from the Grotta Dei Cervi cave in Italy (Jurado et al., 2005a) and Agromyces subbeticus from a cave occupied by bats in Spain (Jurado et al., 2005b). Recently, Amycolatopsis jejuensis, Amycolatopsis halotolerans, Nocardia jejuensis and Nocardia speluncae have been isolated from natural caves (Lee, 2006a, b; Soe et al., 2007).

In the present study a rare actinomycete, strain CMUPNK470, was isolated from a cave soil. Taxonomic characterization identified it as Spirillospora albida based on 16S rRNA gene sequence analysis in combination with biochemical, chemotaxonomic and morphological data. Its ability to produce antimicrobial and anticancer compounds was also investigated.

\section{MATERIALS AND METHODS}

Selective isolation of actinomycetes from a cave soil

A soil sample was collected from Phanangkoi Cave in Phrae province in northern Thailand. The $\mathrm{pH}$, and organic matter and total nitrogen contents of the soil sample were measured. It was sieved and air-dried for 7 days. One gram of soil sample was pretreated with dry heat in a hot air oven at $120^{\circ} \mathrm{C}$ for 1 hour (Nonomura \& Ohara, 1969). One gram of dried soil was suspended in $9 \mathrm{ml}$ of $1.5 \%$ phenol solution for 30 minutes to kill fast-growing soil bacteria. A soil suspension $(0.1 \mathrm{ml})$ was spread onto Humic acid-Vitamin (HV) agar (Hayakawa \& Nonomura, 1987) containing nystatin and cycloheximide at final concentrations of 25 and $10 \mu \mathrm{g} / \mathrm{ml}$, respectively. Plates were incubated at $28^{\circ} \mathrm{C}$ for 20 days. Actinomycete isolates were maintained on Hickey-Tresner (HT) agar (Hickey \& Tresner, 1952).

\section{Phenotypic characteristics}

Strain CMU-PNK470 was cultured on ISP-4 medium (Shirling \& Gottlieb, 1966) and HT agar at $30^{\circ} \mathrm{C}$ for 30 days. Morphological features of the substrate mycelium, aerial mycelium and spores were observed by light microscopy (BH-2, Olympus) and scanning electron microscopy (model JSM-5910, JEOL). The colors of the aerial mycelium, substrate mycelium and soluble pigment were observed on ISP-2, ISP-4 and HT agar using a NBS/IBCC color chart (Mundie, 1995). The temperature range for

${ }^{*}$ Corresponding author and address: Saisamorn Lumyong, Department of Biology, Faculty of Science, Chiang Mai University, Chiang Mai 50200, Thailand., phone: +66-53-941947ext144, e-mail: scboi009@chiangmai.ac.th, fax: +66-53-892259. 
growth was determined on ISP-2 agar. For examination of spore motility, the isolate was cultured on HV agar until spores were formed. The culture was flooded with distilled water or $0.01 \mathrm{M}$ phosphate buffer ( $\mathrm{pH} 7.0$ ) containing $10 \%$ soil extract (Hamaki et al., 2005) and incubated at $28^{\circ} \mathrm{C}$ for 1 hour. Spore motility was observed under the light microscope. Carbohydrate utilization was determined by the method of Pridham \& Gottlieb (1948). Gelatin liquefaction and starch hydrolysis were tested according to Gordon et al. (1974) and Goodfellow (1971), respectively.

\section{Chemotaxonomic characteristics}

Bacterial biomass for the chemotaxonomic studies and molecular identification was obtained after 14 days incubation with shaking at $28^{\circ} \mathrm{C}$ in ISP-2 broth. The isomers of diaminopimelic acid and whole cell organism sugars were examined using standard procedures described by Hasegawa et al. (1983). Menaquinones were extracted and purified following Collins et al. (1977) and analyzed by High Performance Liquid Chromatography (HPLC) (Wu et al., 1989).

\section{Nucleotide sequencing of the 16S rRNA gene}

Genomic DNA was isolated as described by Hopwood et al. (1985). The $16 \mathrm{~S}$ rRNA gene was amplified by PCR using the universal primers 27F (5'-AGAGTTTGATCMTGGCTCAG-3') and 1525R (5'-AAGGAGGTGWTCCARCC-3') (Lane, 1991). The $50 \mu$ l PCR reaction mixture contained $5 \mu \mathrm{l}$ of DNA template, $2 \mu \mathrm{l}$ of $25 \mathrm{mM}$ deoxyribonucleotide triphosphates (dNTPs), $2 \mu$ of each $10 \mu \mathrm{M}$ primer, $0.4 \mu \mathrm{l}$ of Taq DNA polymerase, $5 \mu \mathrm{l}$ of $10 \times$ PCR buffer and $33.6 \mu \mathrm{l}$ of sterilization distilled water. All reactions were preheated at $95^{\circ} \mathrm{C}$ for $5 \mathrm{~min}$ and then 30 cycles of PCR amplification were performed using $95^{\circ} \mathrm{C}$ $1 \mathrm{~min}$ denaturing, $50{ }^{\circ} \mathrm{C} 1 \mathrm{~min}$ annealing, and $72^{\circ} \mathrm{C} 1 \mathrm{~min}$ extension. The reaction was kept at $72^{\circ} \mathrm{C}$ for $10 \mathrm{~min}$ for final extension. PCR products were purified using a QIAquick PCR Purification Kit (Qiagen) and sequenced by Macrogen Inc. (Seoul, Korea). The sequence was compared with all accessible sequences in a database using BLAST software. Multiple sequence alignment and computation of sequence similarity were conducted using ClustalW within the Bioedit program (Hall, 1999). A phylogenetic tree was constructed using the neighborjoining method of Saitou \& Nei (1987) in the Molecular Evolutionary Genetics Analysis (MEGA) program version 4 (Tamura et al., 2007).

\section{Biological activity}

The ability of the CMU-PNK 470 strain to inhibit the growth of bacteria, yeast and filamentous fungi was determined using the agar well method (Barry \& Thornsberry, 1985). The test microorganisms were Bacillus cereus, Escherichia coli, Methicillin-resistant Staphylococcus aureus (MRSA), Pseudomonas aeruginosa, Paenibacillus larvae, Staphylococcus aureus and yeast, Candida albicans. Plant pathogenic filamentous fungi were Colletotrichum, Didymella, Fusarium oxysporum and Sclerotium solani. All of the test organisms were obtained from the Excellent on Sustainable Development of Biodiversity Resources Center, Chiang Mai University, Thailand. Strain CMU-PNK470 was grown in antibiotics production media for 20 days on shaking incubation at $30^{\circ} \mathrm{C}$. The culture broth was then extracted with ethyl acetate. The minimum inhibitory concentration of the crude extract was determined and defined as the lowest concentration of crude extract at which there was no visible growth of test microorganisms. The anti-cancer assay of crude extract against cancer cell lines was also determined by Sulphorhodamine B (SRB) assay (Skehan et al., 1990). Doxorubicin and ellipticine were used as a positive control and DMSO as a negative control. Three cancer cell lines, Human breast cancer (MCF7), Human oral cavity cancer (KB), and Human small cell lung cancer (NCI-H187) were used in this study. The maximum concentration of the tested samples was $50 \mu \mathrm{g} / \mathrm{ml}$.

\section{RESULTS AND DISCUSSION}

The soil sample had a $\mathrm{pH}$ of 8.29 , with organic matter and total nitrogen contents of $15.26 \%$ and $0.841 \%$ respectively A total of 78 actinomycetes were selectively isolated on Humic acid-Vitamin (HV) agar. One isolate, designated as CMU-PNK470, was selected for detailed studies as it showed distinct morphological and chemical characteristics and produced a diffusible blue pigment in HT agar.

Strain CMU-PNK470 was grown on several media to enable cultural characterization. The strain grew very slowly on all tested media. It formed very small colonies and rarely formed aerial mycelium. The colony was deep violet purple on ISP-2 but white on ISP-4 and HT agars. Diffusible pigments were purplish blue on ISP-4 and HT agar plates and deep violet purple on ISP-2 agar (Table 1). Spherical sporangia with diameters of $5 \mu \mathrm{m}$ (Fig. 1) were formed on aerial mycelium after cultivation on ISP-4 agar for 30 days.

Strain CMU-PNK470 was examined for key phenotypic markers in order to determine whether it had a chemotaxonomic profile consistent with its classification in the genus Spirillospora. Strain CMU-PNK470 has chemical properties consistent with its assignment to the genus Spirillospora (Couch 1963). It contains meso-diaminopimelic acid in cell wall hydrolysates as the characteristic cell wall diamino acid with madurose, galactose and arabinose as diagnostic sugars. The major menaquinones were MK-9 $\left(\mathrm{H}_{6}\right)$, MK-9 $\left(\mathrm{H}_{4}\right)$ and MK-9 $\left(\mathrm{H}_{8}\right)$. The motility of its sporangiospores were also shown. These phenotypic properties were consistent with the description of the genus Spirillospora.

For phytogenetic analysis, the $16 \mathrm{~S}$ rRNA gene sequence of strain CMU-PNK470 was submitted to GenBank under 
Table 1. Phenotypic characteristics of strain CMU-PNK470 and related species

\begin{tabular}{|c|c|c|c|}
\hline Characteristics & CMU-PNK470 & $\begin{array}{l}\text { Spirillospora albida } \\
\text { NBRC } 12248^{\mathrm{T} *}\end{array}$ & $\begin{array}{c}\text { Spirillospora rubra } \\
\text { JCM } 6875^{\mathrm{T} * *}\end{array}$ \\
\hline Growth on ISP2 & AM: -; SM: purple; SP: purple & AM: white; SM: beige; SP: - & ND \\
\hline Growth on ISP4 & AM: white; SM: pale purple; SP: purple & AM: white; SM: beige; SP: - & ND \\
\hline Motile spore formation & + & + & + \\
\hline Production of sporangia & + & + & + \\
\hline Production of Citrate lyase & + & ND & ND \\
\hline \multicolumn{4}{|l|}{ Degradation of: } \\
\hline Tyrosine & + & + & - \\
\hline Gelatin & - & - & + \\
\hline Starch & - & ND & ND \\
\hline Casein & + & + & + \\
\hline$(+)$-D-Cellobiose & + & - & ND \\
\hline Myo-inositol & + & - & ND \\
\hline (-)-D-Lactose & - & ND & ND \\
\hline (-)-D-Mannitol & - & + & ND \\
\hline (+)-L-Rhamnose & - & - & ND \\
\hline (+)-D-Xylose & - & - & ND \\
\hline D-Fructose & + & ND & ND \\
\hline D-Mannose & + & ND & ND \\
\hline D-Raffinose & + & ND & ND \\
\hline L-Arabinose & - & ND & ND \\
\hline Sucrose & + & ND & ND \\
\hline
\end{tabular}

$\mathrm{AM}=$ aerial mycelium, $\mathrm{SM}=$ substrate mycelium, $\mathrm{SP}=$ soluble pigment, $\mathrm{ND}=$ Not determined, ${ }^{*}$ Data taken from ${ }^{*}$ Rose $\&$ Meyers 2007, ${ }^{* *}$ Goodfellow 1989

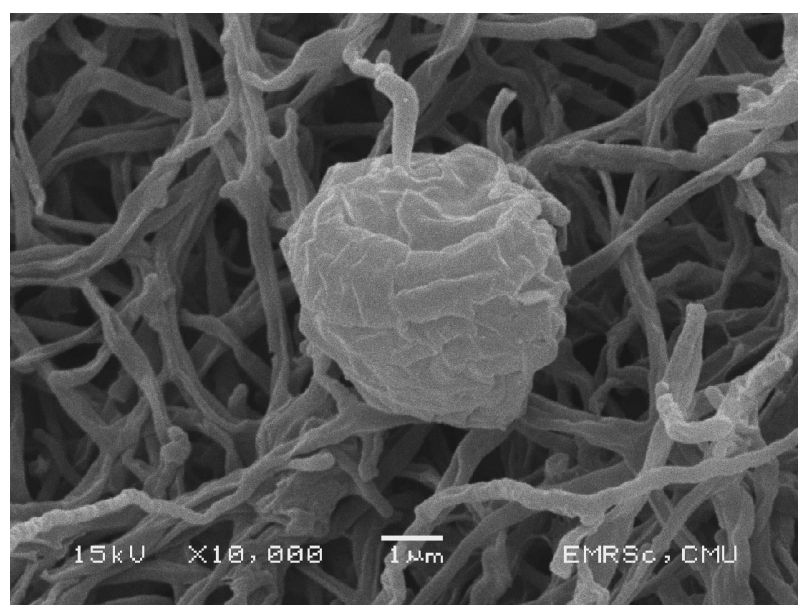

Fig. 1. Scanning electron micrograph of CMU-PNK470 cultured on ISP-4 medium for 30 days at $30^{\circ} \mathrm{C}$.

the accession number EU399546. It is evident from Figure 2 that this strain belongs to the genus Spirillospora and is closely related to Spirillospora albida NBRC12248 ${ }^{\mathrm{T}}$. This relationship is supported by a high bootstrap value of 94\%. Strain CMU-PNK470 shared 98.86\% 16S rRNA sequence similarity to Spirillospora albida $\mathrm{NBRC}^{2} 248^{\mathrm{T}}$, a value that corresponds to 16 nucleotide differences at the 1408 locations available for alignment (Table 2). The high level of $16 \mathrm{~S}$ rDNA sequence similarity suggests that strain
CMU-PNK470 should be identified as Spirillospora albida. A 16S rRNA sequence similarity of $97.21 \%$ was observed between strain CMU-PNK470 and Spirillospora rubra JCM6875 ${ }^{\mathrm{T}}$. Also, they were located on a different clade although they belong to the same genus. A similar observation was reported by Zhang et al. (2001) who suggested that $S$. rubra should be separated as an independent genus. Due to $S$. albida being located on the same clade of Actinomadura and being more closely related than S. rubra, Zhang et al. (2001) suggested that the lateral transfer of a distant gene cluster source produced a unique morphology in an ancestor of Spirillospora. Consequently, they suggested combining them. Further studies are need to clarify the relationship between $S$. albida and S. rubra.

Phenotypic comparisons between strain CMU-PNK470 and related species are shown in Table 1. Unfortunately there is little phenotypic information relating to this genus available for comparison. However, strain CMU-PNK470 may represent a new species within the genus Spirillospora because a higher 16S rDNA similarity was found between representatives of validly described members of the family Thermomonosporaceae such as Actinomadura citrea and Actinomadura coerulea which shared $99.4 \%$ similarity. The clarification of the taxonomic status of strain CMUPNK470 requires further investigation.

Spirillospora albida is very difficult to cultivate due to its slow growth. Hence, there has been little published information describing its distribution, isolation and bio- 


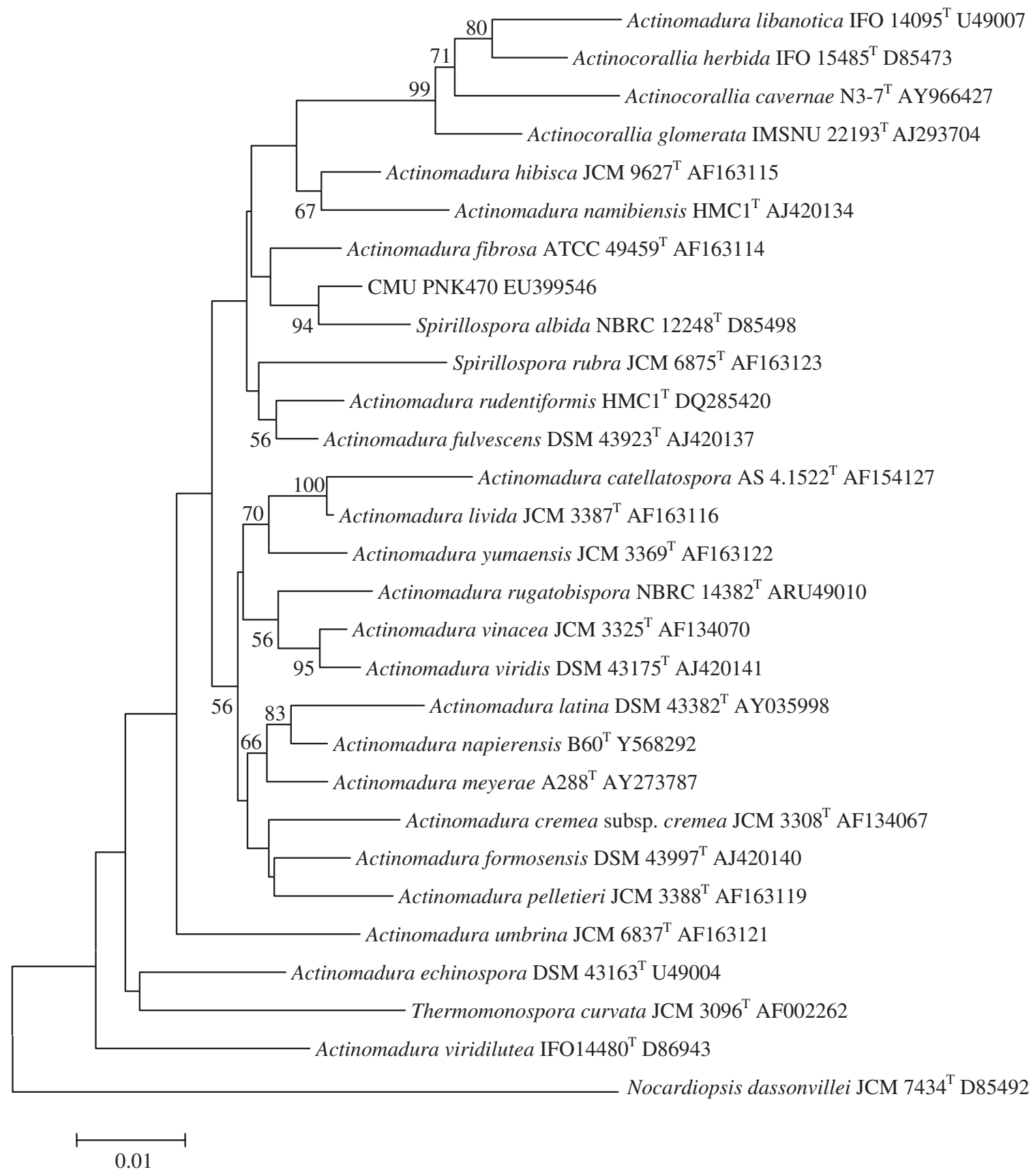

Fig. 2. Neighbor-joining phylogenetic tree, based on 16S rRNA gene sequences, showing the position of Spirillospora albida CMUPNK 470 amongst its related neighbors. The number of branches indicated the percentage bootstrap values of 1,000 replicates (greater than $50 \%$ ).

Bar, 0.01 nucleotide substitutions per position.

active compound production since the identification of Spirillospora as a separate genus. Spirillomycin is the only known specific antibiotic produced by this genus (Domnas, 1968). Hacène et al., (1994) and Hacène \& Lefebvre (1995, 1996) reported that Spirillospora strain 719 from a soil sample in the Algerian Sahara produced several unspecified antibiotics including a new deep red pigment-like antibacterial HP17, which could inhibit the growth of coccoidal
Gram-positive bacteria, a new polyene antifungal HM17 and a broad spectrum antibiotic, AH17. There have been no reports of anticancer compounds produced from members of the genus Spirillospora. Thus, the antibiotic activity of strain CMU-PNK470 was investigated. It showed an ability to produce an anti-Gram-positive bacteria substance which was active against Bacillus cereus, a clinical isolate of Methicillin-resistant Staphylococcus aureus (MRSA) and 


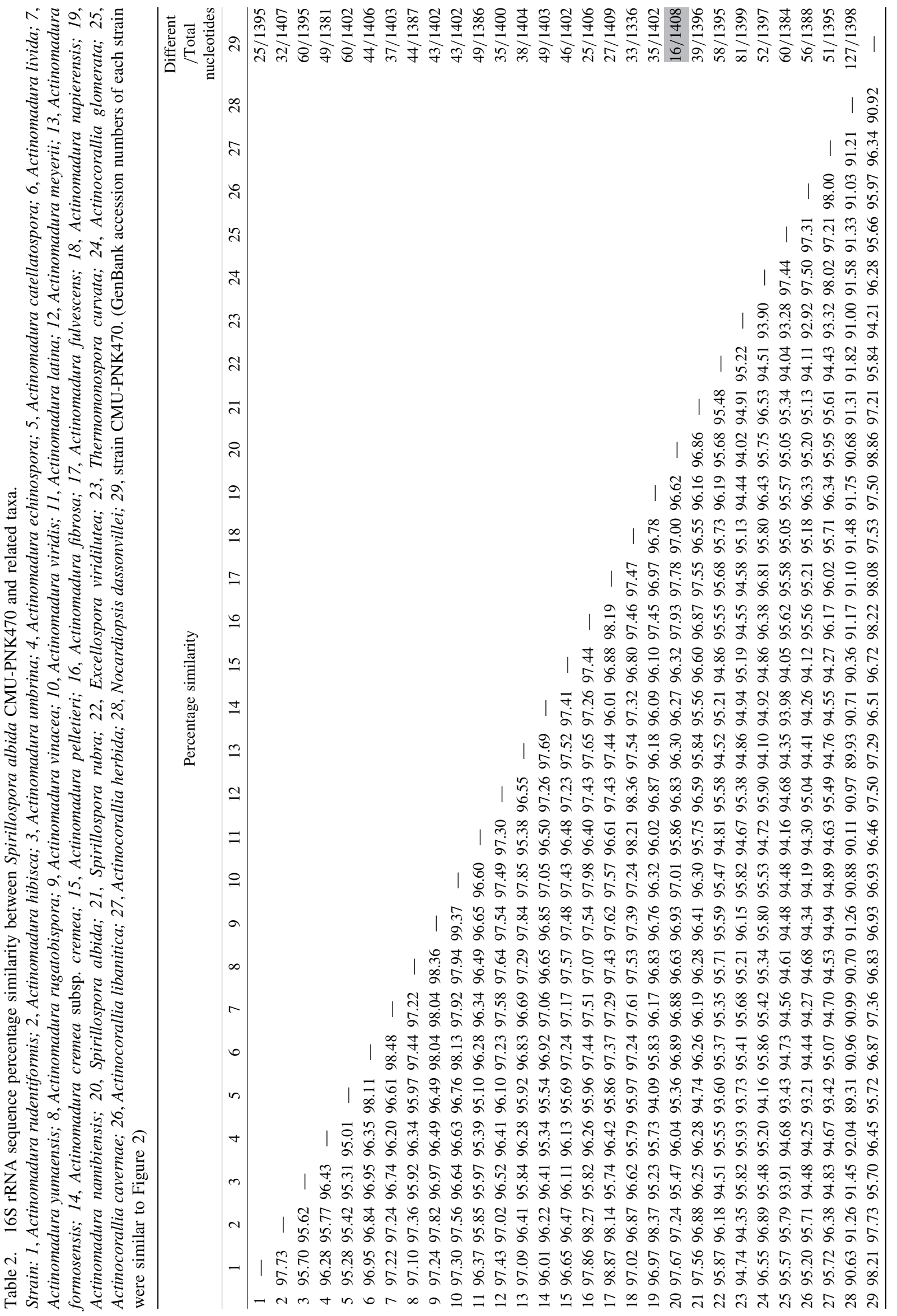


Paenibacillus larvae, a causative agent of American Foulbrood in honey bees. The MIC value of the antimicrobial extracted from strain CMU-PNK470 against Bacillus cereus and Methicillin-resistant Staphylococcus aureus was $23.1 \mu \mathrm{g} / \mathrm{ml}$ and against Paenibacillus larvae was $185 \mu \mathrm{g} /$ ml. Also, a crude extract of strain CMU-PNK470 showed anticancer activity against human small lung cancer cells (NCI-H187) with an $\mathrm{IC}_{50}$ value of $10.18 \mu \mathrm{g} / \mathrm{ml}$. This result encourages us to investigate this compound in the future.

We conclude from the genotypic and phenotypic data that strain CMU-PNK470 represents a new strain within the species Spirillospora albida. This is the first reported isolation of Spirillospora albida from a cave soil. The strain showed biological activity against selected pathogenic Gram-positive bacteria and cancer cell lines. The results obtained show the potential value of this strain as a source of novel bioactive compounds. Hence, it merits further studies to purify and characterize the active components. This study also supports the hypothesis that rare microorganism are a promising source of new bioactive compounds.

\section{ACKNOWLEDGEMENTS}

This work was supported by a grant from the Graduate School, Chiang Mai University and the Nanotechnology Research Fund, Faculty of Science, Chiang Mai University, Chiang Mai, Thailand.

\section{REFERENCES}

Ara, I., Bakir, M.A. \& Kudo, T. (2008). Transfer of Catellatospora koreensis Lee et al. 2000 as Catelliglobosispora koreensis gen. nov., comb. nov. and Catellatospora tsunoense Asano et al. 1989 as Hamadaea tsunoensis gen. nov., comb. nov., and emended description of the genus Catellatospora Asano and Kawamoto 1986 emend. Lee and Hah 2002. Int. J. Syst. Evol. Microbiol. 58, 1950-1960.

Barry, A.L. \& Thornsberry, C. (1985). Susceptibility tests: diffusion test procedure. In Manual Of Clinical Microbiology, $4^{\text {th }}$ edn., eds. Ballows, E.A., Hawsler, W.J. Jr. \& Shadomy, H.I. pp. 978-987. Washington DC: American Society of Microbiology.

Barton, H.A. (2006). Introduction to cave Microbiology: a review for the non-specialist. J. Cave Karst Stud. 68(2), 43-54.

Collins, M.D., Pirouz, T., Goodfellow, M. \& Minnikin, D.E. (1977). Distribution of menaquinones in actinomycetes and corynebacteria. J. Gen. Microbiol. 100, 221-230.

Couch, J.N. (1963). Some new genera and species of Actinoplanaceae. J. Elisha. Mitchell. Sci. Soc. 79, 54-70.

Domnas, A. (1968). Pigments of Actinoplanaceae I. Pigment production by Spirillospora 1655. J. Elisha. Mitchell. Sci. Soc. 84, 16-23.

Goodfellow, M. (1971). Numerical taxonomy of some nocardioform bacteria. J. Gen. Microbiol. 69, 33-80.

Goodfellow, M. (1989). Maduromycetes. In Bergey's Manual of Systematic Bacteriology, vol. 4, pp. 2509-2551. Edited by S. T. Williams, M. E. Sharpe \& J. G. Holt. Baltimore: Williams \&
Wilkins.

Gordon, R.E., Barnett, D.A., Handerhan, J.E. \& Pang, C.H.N. (1974). Nocardia coeliaca, Nocardia autotrophica and the nocardin strain. Int. J. Syst. Bacteriol. 24, 54-63.

Hacène, H., Kebir, K., Othmane, D.H. \& Lefebvre, G. (1994). HM17, a new polyene antifungal antibiotic produced by a new strain of Spirillospora. J. Appl. Bacteriol. 77, 484-489.

Hacène, H. \& Lefebvre, G. (1995). AH17, a new non polyenic antifungal antibiotic produced by a strain of Spirillospora. Microbios. 83, 199-205.

Hacène, H. \& Lefebvre, G. (1996). HP17, a new pigment-like antibiotic produced by a new strain of Spirillospora. J. Appl. Bacteriol. 89, 565-569.

Hall, T.A. 1999. BioEdit: a user-friendly biological sequence alignment editor and analysis program for Windows 95/98/NT. Nucleic Acids Symp. Ser. 41, 95-98.

Hamaki, T., Suzuki, M., Fudou, R., Jojima, Y., Kajiura, T., Tabuchi, A., Sen, K. \& Shibai, H. (2005). Isolation of novel bacteria and actinomycetes using soil-extract agar medium. $J$. Biosci. Bioeng. 99, 485-492.

Hasegawa, T., Takizawa, M. \& Tanida, S. (1983). A rapid analysis for chemical grouping of aerobic Actinomycetes. $J$. Gen. Appl. Microbiol. 29, 319-322.

Hayakawa, M. \& Nonomura, H. (1987). Humic acid-vitamin agar, a new medium for the selective isolation of soil actinomycetes. J. Ferm. Technol. 65, 501-509.

Hickey, R.J. \& Tresner, H.D. (1952). A cobalt-containing medium for sporulation of Streptomyces species. J. Bacterial. 64, 891-892.

Hopwood, D.A., Bibb, M.J., Chater, K.F., Kieser, T., Bruton, C.J., Kieser, H.M., Lydiate, D.J., Smith, C.P., Ward, J.M. \& Schrempf, H. (1985). Genetic Manipulation of Streptomyces. A Laboratory Manual. John Innes Foundation Norwich. UK.

Jurado, V., Groth, I., Gonzalez, J.M., Laiz, L. \& Saiz-Jimenez, C. (2005a). Agromyces salentinus sp. nov. and Agromyces neolithicus sp. nov. Int. J. Syst. Evol. Microbiol. 55, 153-157.

Jurado, V., Groth, I., Gonzalez, J.M., Laiz, L. \& Saiz-Jimenez, C. (2005b). Agromyces subbeticus sp. nov., isolated from a cave in southern Spain. Int. J. Syst. Evol. Microbiol. 55, 18971901.

Lane, D.J. (1991) 16S/23S rRNA sequencing. In nucleic acid techniques in bacterial systematics, pp. 115-148. Edited by E. Stackebrandt \& M. Goodfellow. Chichester: John Wiley \& Son.

Lazzarini, A., Linda, C., Giorgio, T. \& Flavia, M. (2000). Rare genera of actinomycetes as potential producers of new antibiotics. Antonie van Leeuwenhoek. 78, 399-405.

Lee, S.D. (2006a). Amycolatopsis jejuensis sp. nov. and Amycolatopsis halotolerans sp. nov., novel actinomycetes isolated from a natural cave. Int. J. Syst. Evol. Microbiol. 56, 549-533.

Lee, S.D. (2006b). Nocardia jejuensis sp. nov., a novel actinomycete isolated from a natural cave on Jeju Island, Republic of Korea. Int. J. Syst. Evol. Microbiol. 56, 559-562.

Mundie, D.A. (1995). The NBS/ISCC Color System/David A. Mundie Pittsburgh, PA: Polymath Systems 535.6 dc-20 (http:// www.anthus.com/Colors/Cent.html, last access February 2006).

Nonomura, H. \& Ohara, Y. (1969). The distribution of actinomycetes in soil. VI. A selective plate culture isolation method for Microbispora and Streptosporangium strains Part I. J. Ferm. Technol. 47, 463-469.

Pridham, T.G. \& Gottlieb, G. (1948). The utilization of carbon compounds by some Actinomycetales, an aid for species 
determination. J. Bacteriol. 56, 107-114.

Rose, M.I. \& Meyers, P.R. (2007). Actinomadura rudentiformis sp. nov., isolated from soil. Int. J. Syst. Evol. Microbiol. 57, 4550 .

Saitou, N. \& Nei, M. (1987). The neighbor-joining method: a new method for reconstructing phylogenetic trees. Mol. Biol. Evol. 4, 406-425.

Schabereiter-Gurtner, C., Saiz-Jimenez, C., Piñar, G., Lubitz, W. \& Rölleke, S. (2002). Altamira Cave Paleolithic paintings harbour partly unknown bacterial communities. FEMS Microbiol. Lett. 211, 7-11.

Shirling, E.B. \& Gottlieb, D. (1966). Methods for characterization of Streptomyces species. Int. J. Syst. Bacteriol. 16, 313340.

Skehan, P., Storeng, R., Scudiero, D., Monks, A., McMahon, J., Vistica, D., Warren, J.T., Bokesch, H., Kenney, S. \& Boyd, M.R. (1990). New colorimetric cytotoxicity assay for anticancer drug screening. J. National. Cancer. Insti. 82, 11071112 .
Soe, J.P., Yun, Y.W. \& Lee, S.D. (2007). Nocardia speluncae sp. nov., isolated from a cave. Int. J. Syst. Evol. Microbiol. 57, 2932-2935.

Tamura, K., Dudley, J., Nei, M. \& Kumar, S. (2007). MEGA4: molecular evolutionary genetics analysis (MEGA) software version 4.0. Mol. Biol. Evol. 24(8), 1596-1599.

Wu, C., Lu, X., Qin, M., Wang, Y. \& Ruan, J. (1989). Analysis of menaquinone compound in microbial cells by HPLC. Microbiology 16, 176-178.

Zhang, Z., Kudo, T., Nakajima, Y. \& Wang, Y. (2001). Clarification of the relationship between the members of the family Thermomonosporaceae on the basis of $16 \mathrm{~S}$ rDNA, 16S23S rRNA internal transcribed spacer and 23S rDNA sequences and chemotaxonomic analyses. Int. J. Syst. Evol. Microbiol. 51, 373-383.

Zhang, Z., Wang, Y. \& Ruan, J. (1998). Reclassification of Thermomonospora and Microtetraspora. Int. J. Syst. Bacteriol. 48, 411-422. 